\title{
'COLLAGENASE-LIKE' PEPTIDASE IN HUMAN, RAT AND BULL SPERMATOZOA
}

\author{
E. KOREN AND S. MILKOVIĆ \\ Laboratory for Experimental Medicine, University of Zagreb, \\ Vinogradska c. 29, 41000 Zagreb, Tugoslavia
}

(Received 17th March 1972)

\begin{abstract}
Summary. A peptidase capable of splitting synthetic collagenase substrate and collagen peptides, 'collagenase-like' peptidase, has been discovered in human semen, rat and bull epididymal spermatozoa and rat and bull testes. This enzyme is also present in human seminal plasma and sperm washings, but its total activity pattern in human semen fractions, its specific activity in washed spermatozoa and the negligible activity found in the azoöspermic ejaculate prove that it is a sperm enzyme. As shown by the thin-layer chromatography of the reaction products, 'collagenase-like' peptidase cleaves synthetic collagenase substrate at the same site as bacterial collagenase does. The $\mathrm{pH}$ optimum of the 'collagenase-like' peptidase is $\mathbf{7 \cdot 5}$.

The enzyme has been partially purified from rat testis homogenate by ammonium sulphate saturation and gel filtration on a Sephadex G-200 column. Its molecular weight appears to be about 110,000. The possible rôle of this enzyme in fertilization is discussed.
\end{abstract}

\section{INTRODUGTION}

An increasing number of authors are coming to believe that the proteolytic enzymes in spermatozoa (Stambaugh \& Buckley, 1968, 1969, 1970; Stambaugh, Brackett \& Mastroianni, 1969; Allison \& Hartree, 1970; Zaneveld \& Williams, 1970) and seminal plasma (Moghissi \& Syner, 1970; Syner \& Moghissi, 1972) play a rôle in the fertilization process.

This paper presents evidence for the existence of a 'collagenase-like' peptidase in human, rat and bull spermatozoa as well as in rat and bull testes.

\section{MATERIALS AND METHODS}

Synthetic PZ-pentapeptide or 'collagenase chromophore substrate' (4-phenylazo-benzyloxy-carbonyl-L-prolyl-L-leucyl-L-glycyl-L-prolyl-D-arginine) and PZdipeptide (4-phenylazo-benzyloxy-carbonyl-L-prolyl-L-leucin) were purchased from Fluka, Buchs, Switzerland. Bacterial collagenase and alpha casein were obtained from Worthington Biochemical Corporation, U.S.A.; bovine serum albumin (monomer) and human serum $\gamma$-globulin from Calbiochem, U.S.A.; 
and porcine insulin from Pliva, Zagreb, Yugoslavia. Acid-soluble rat skin collagen was prepared according to the method of Lapière \& Gross (1965).

\section{Fractionation of human semen}

Human semen obtained from healthy donors was allowed to liquefy at room temperature and then diluted with $0.9 \%$ sodium chloride to double the original volume (usually 6 to $7 \mathrm{ml}$ ). Aliquots $(2 \mathrm{ml}$ ) of the diluted semen homogenized with a Teflon homogenizer at low speed and freeze-thawed twice were used as whole semen homogenates.

Four $\mathrm{ml}$ of the diluted semen were centrifuged for $15 \mathrm{~min}$ at $3000 \mathrm{rev} / \mathrm{min}$ and the supernatant was used as diluted seminal plasma. The sperm pellet was resuspended in $0.9 \%$ sodium chloride to the starting volume $(4 \mathrm{ml})$, homogenized and freeze-thawed twice. Aliquots of this preparation were used as homogenates of unwashed spermatozoa. By the same procedure, seminal plasma from an azoöspermic ejaculate was also obtained.

To obtain washed spermatozoa, the method of Allison \& Hartree (1970) four washings with hypotonic tris buffer-was strictly followed. The final washed sperm pellet was resuspended in $0.9 \%$ sodium chloride to the starting volume of the ejaculate, then homogenized and freeze-thawed twice. The washings were also homogenized and freeze-thawed.

\section{Fractionation of spermatozoa and testis tissue of rat and bull}

Rat epididymal spermatozoa, flushed from the epididymides of fifteen 6-month-old Fischer strain rats immediately after the animals had been killed, were washed according to the procedure for human spermatozoa. The tunica albuginea of both testes from the same animals was emptied by squeezing out the testicular tissue, which was first homogenized and then diluted in $0.9 \%$ sodium chloride to $1: 10$, tissue : sodium chloride, ratio. Bull epididymal spermatozoa and testis homogenates were subjected to the same procedure as rat epididymal spermatozoa and testis homogenates.

\section{Determination of 'collagenase-like' peptidase activity}

The activity of 'collagenase-like' peptidase (CLP) was determined with PZ-pentapeptide (Wünsch \& Heidrich, 1963). Samples $(1 \mathrm{ml}$ ) for analysis were incubated at $37^{\circ} \mathrm{C}$ with $1 \mathrm{ml} 0.15 \mathrm{M}$-tris-acetate buffer, $\mathrm{pH} 7.5$, containing $0.2 \mathrm{mg}$ PZ-pentapeptide. After $60 \mathrm{~min}$, the reaction was stopped by lowering the $\mathrm{pH}$ to 3 with $0.5 \mathrm{ml} 0.47 \mathrm{M}$-citric acid, and the released PZ-Pro-Leu was extracted with $3 \mathrm{ml}$ ethyl acetate. Undegraded PZ-pentapeptide remained in the watery phase because it was not soluble in ethyl acetate at this $\mathrm{pH}$. The concentration of PZ-Pro-Leu was determined from the extinction at $320 \mathrm{~m} \mu$ (Strauch \& Vencelj, 1967).

The unit of enzyme activity was defined as the amount of enzyme that releases $1 \mu \mathrm{g}$ of PZ-Pro-Leu under the above conditions. Total activities were calculated back to $1 \mathrm{ml}$ of semen and specific activities were expressed as units per mg protein.

The optimal $\mathrm{pH}$ of CLP was determined in the $\mathrm{pH} 4$ to 9 range by incubating $1-\mathrm{ml}$ aliquots of various samples for $60 \mathrm{~min}$ at $37^{\circ} \mathrm{C}$ with $2 \mathrm{ml}$ of $0.15 \mathrm{M}$-tris- 
acetic acid buffer containing $0.2 \mathrm{mg}$ of PZ-Pro-Leu-Gly-Pro-D-Arg. The $\mathrm{pH}$ of each incubation mixture was checked at the beginning and end of incubation.

The site of cleavage of the PZ-Pro-Leu-Gly-Pro-D-Arg substrate was determined by thin-layer chromatography of the ethyl acetate extracted reaction products on silica gel $G$ with butanol : acetic acid : water-6:2:2 (Heidrich, Prokopova \& Hannig, 1969). The chromatograms were sprayed with concentrated $\mathrm{H}_{2} \mathrm{SO}_{4}$.

Total protein concentration was determined by the spectrophotometric method of Waddell (1956), and caseinolytic activity in the rat testis homogenate and the purified CLP preparation was determined according to the method of Kunitz (1947).

\section{Purification of CLP from rat testis tissue}

The testis homogenate prepared from thirty-three testes of 6-month-old rats (about $30 \mathrm{~g}$ ) was diluted with $0.9 \% \mathrm{NaCl}$ (buffered with $0.5 \mathrm{M}$-tris to $\mathrm{pH} 7.5$ ) to $300 \mathrm{ml}$ and clarified by centrifugation $\left(12,000 \mathrm{~g}\right.$ for $10 \mathrm{~min}$ at $\left.4^{\circ} \mathrm{C}\right)$. The supernatant was fractionated with ammonium sulphate saturation (Dixon \& Webb, 1961) to give $20,40,50,60$ and $70 \%$ saturation precipitates. Each was dissolved in $10 \mathrm{mI} 0.15 \mathrm{M}$-tris-acetate buffer, clarified by centrifugation and then passed through a Sephadex G-25 coarse column $(1.5 \times 40 \mathrm{~cm})$ to remove the ammonium sulphate. Protein concentration and CLP activity were determined.

Ten $\mathrm{ml}$ of the pooled 50 to $60 \%$ and 60 to $70 \%$ saturation fractions, which showed the highest specific CLP activity, were transferred to a Sephadex G-200 column $(89 \times 2.5 \mathrm{~cm})$. The column was equilibrated and eluted with 0.1 M-tris- $\mathrm{HCl}$ buffer, $\mathrm{pH} 8$, containing $1 \mathrm{M}-\mathrm{NaCl}$, at a rate of $15 \mathrm{ml} / \mathrm{hr}$. The eluate was monitored at $280 \mathrm{~m} \mu$. Five-ml fractions were collected and the CLP activity was determined in each fraction. Fractions 32 and 33 which showed the highest activity were pooled, dialysed against distilled water and freeze-dried. The pooled fractions were used in further experiments as purified rat CLP.

The molecular weight of the enzyme was approximated by the $\mathrm{Ve} / \mathrm{Vo}-\mathrm{log}$ molecular weight plot. The column was calibrated with dextran blue (mol. wt $2 \times 10^{6}$ ), human serum $\gamma$-globulin (mol. wt $1.4 \times 10^{5}$ ), bovine serum albumin (mol. wt $\left.6.7 \times 10^{4}\right)$ and $\mathrm{Fe}\left(\mathrm{CN}_{6}\right)^{3-}\left(\mathrm{mol}\right.$. wt $\left.2.12 \times 10^{2}\right)$.

The effect of purified rat CLP on rat skin collagen was observed by polyacrylamide disc electrophoresis (Reisfeld, Lewis \& Williams, 1962) using Shandon apparatus and the Kipp and Zonen (Holland) densitometer DD2 with BD5 micrograph and BCI integrator. Two incubation mixtures were prepared: one contained $4 \mathrm{mg}$ heat-denatured collagen and the other, $4 \mathrm{mg}$ native rat collagen, in addition to $15 \mathrm{mg}$ purified rat CLP dissolved in $2 \mathrm{ml} 0.15$ M-Krebs-Ringer phosphate buffer, $\mathrm{pH}$ 7.5. From both incubation mixtures, $30-\mu \mathrm{l}$ samples were taken after 0,1 and $2 \mathrm{hr}$ of incubation and immediately mixed with the sample gel. The action of CLP was stopped by urea, the concentration of which in the sample gel was $8 \mathrm{M}$.

By the above procedure and densitometry of gels, an attempt was made to follow the action of purified rat CLP on bovine serum albumin and porcine insulin after 1,2 and $4 \mathrm{hr}$ of incubation at $37^{\circ} \mathrm{C}$ and $\mathrm{pH} 7 \cdot 5$. 


\section{RESULTS}

The distribution of CLP activity in human semen fractions is presented in Tables 1 and 2.

In the seminal plasma of an azoöspermic ejaculate, the total CLP activity amounted to 0.75 units. Microscopic examination revealed some spermatozoa in all four washings, but cytoplasmic droplets could not be demonstrated in washed sperm preparations.

Table 1. Total CLP activity, total protein content and specific CLP activity in various fractions of human semen

\begin{tabular}{|c|c|c|c|}
\hline $\begin{array}{l}\text { Human semen } \\
\text { fractions }\end{array}$ & $\begin{array}{c}\text { Total CLP activity } \\
\text { (units/ml semen) }\end{array}$ & $\begin{array}{l}\text { Total protein content } \\
(\mathrm{mg} / \mathrm{ml} \text { semen })\end{array}$ & $\begin{array}{l}\text { Specific CLP activity } \\
\text { (units/mg protein) }\end{array}$ \\
\hline $\begin{array}{l}\text { Whole ejaculate homogenate } \\
\text { Seminal plasma } \\
\text { Unwashed sperm homogenate }\end{array}$ & $\begin{array}{ll}36.02 \pm 2.56 * & (17) \\
12.47 \pm 1.68 & (20) \\
21.15 \pm 3.01 & (20)\end{array}$ & $\begin{array}{l}65 \cdot 92 \pm 5 \cdot 17(9) \\
50 \cdot 54 \pm 3 \cdot 80(9) \\
19 \cdot 17 \pm 2 \cdot 15(9)\end{array}$ & $\begin{array}{l}0 \cdot 54 \\
0 \cdot 24 \\
1 \cdot 10\end{array}$ \\
\hline
\end{tabular}

* Mean \pm S.E. CLP, 'Collagenase-like' peptidase. ( ) number of estimations.

Table 2. Total CLP activity, total protein content and specific CLP activity in four sperm washings and washed human spermatozoa

\begin{tabular}{|c|c|c|c|}
\hline Material & $\begin{array}{c}\text { Total CLP activity } \\
\text { (units/ml semen) }\end{array}$ & $\begin{array}{l}\text { Total protein content } \\
\quad(\mathrm{mg} / \mathrm{ml} \text { semen })\end{array}$ & $\begin{array}{l}\text { Specific CLP activity } \\
\quad \text { (units/mg protein) }\end{array}$ \\
\hline $\begin{array}{l}W_{1} \\
W_{2} \\
W_{3} \\
W_{4} \\
\text { Washed spermatozoa }\end{array}$ & $\begin{array}{cc}22 \cdot 39 \pm 3 \cdot 30^{*} & (11) \\
2 \cdot 03 \pm 0.25 & (12) \\
1.36 \pm 0.17 & (12) \\
0.68 \pm 0 \cdot 10 & (12) \\
6.01 \pm 0.39 & (16)\end{array}$ & $\begin{array}{c}50 \cdot 62 \pm 3 \cdot 76(9) \\
3 \cdot 49 \pm 0.19(9) \\
2 \cdot 23 \pm 0.13(9) \\
1 \cdot 60 \pm 0.07(9) \\
1.61 \pm 0.22(9)\end{array}$ & $\begin{array}{l}0.44 \\
0.58 \\
0.60 \\
0.42 \\
3 \cdot 73\end{array}$ \\
\hline
\end{tabular}

* Mean \pm S.E. GLP, 'Collagenase-like' peptidase. $W_{1}, W_{2}, W_{3}, W_{4}$, four sperm washings. () number of estimations.

Table 3. Specific CLP activity in rat and bull testis homogenates and washed rat and bull epididymal spermatozoa

\begin{tabular}{l|c|c}
\hline \multicolumn{1}{c|}{ Material } & $\begin{array}{c}\text { Specific CLP activity } \\
\text { (units/mg protein) }\end{array}$ & $\begin{array}{c}\text { No. of } \\
\text { estimations }\end{array}$ \\
\hline Rat testis homogenate & $3 \cdot 25$ & 11 \\
Bull testis homogenate & $2 \cdot 36$ & 4 \\
Washed rat epididymal spermatozoa & $3 \cdot 66$ & 11 \\
Washed bull epididymal spermatozoa & $4 \cdot 24$ & 4 \\
\hline
\end{tabular}

GLP, 'collagenase-like' peptidase.

Table 3 shows CLP activities in rat and bull testis and epididymal spermatozoa. The optimal $\mathrm{pH}$ for CLP activity in rat testis homogenate, rat epididymal sperm homogenate, human washed sperm homogenate, bovine epididymal sperm homogenate, and for purified rat testis GLP was 7.5.

Thin-layer chromatography showed that all these preparations, as well as human seminal plasma and bacterial collagenase, split PZ-Pro-Leu-Gly-Pro-DArg between Leu and Gly. In all cases, ethyl acetate extracts of the incubation 
mixtures gave only one yellow spot on the chromatogram which had the same $R_{F},(0 \cdot 86)$ as the PZ-Pro-Leu test substance.

By gel filtration of $10 \mathrm{ml}$ of pooled 50 to $60 \%$ and 60 to $70 \%$ ammonium

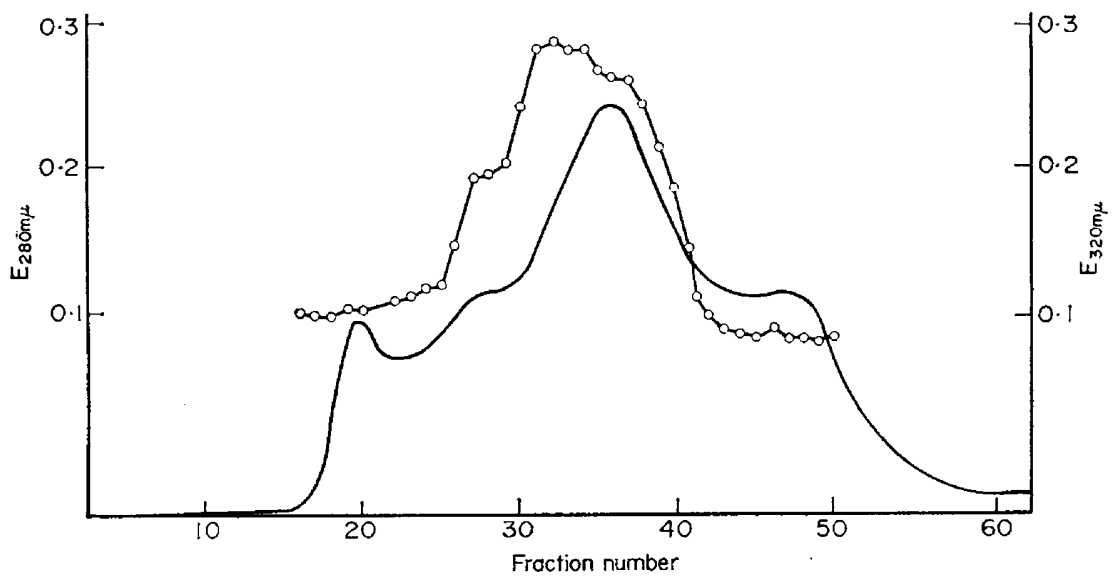

TexT-Fig. 1. Gel filtration of $10 \mathrm{ml}$ pooled 50 to $60 \%$ and 60 to $70 \%\left(\mathrm{NH}_{4}\right)_{2} \mathrm{SO}_{4}$ fractions of the rat testis homogenate on Sephadex G-200 column $(89 \times 2.5 \mathrm{~cm})$. - - Protein, extinction at $280 \mathrm{~m} \mu$; O, CLP activity, extinction at $320 \mathrm{~m} \mu$.

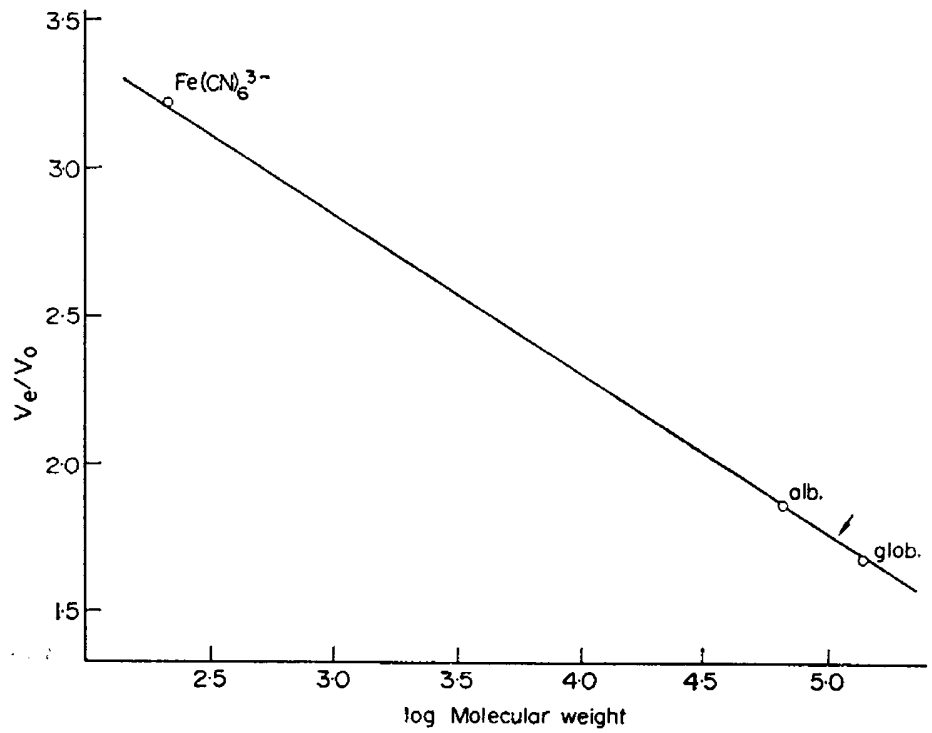

TexT-FIO. 2. Determination of the molecular weight of rat testis CLP. A calibration curve of known proteins on a Sephadex G-200 column $(89 \times 2.5 \mathrm{~cm})$. alb. = bovine serum albumin; glob. $=$ human serum $\gamma$-globulin. The arrow points to the elution position of CLP. Void volume $=133 \mathrm{ml}$, elution volume $=232 \mathrm{ml}$ for rat testis CLP.

sulphate saturation fractions of the rat testis homogenate, four protein peaks and one GLP activity peak were obtained. Total CLP activity in the eluate was recovered at a $60 \%$ rate (Text-fig. 1 ). 
During the purification procedure of the rat testis CLP, a decrease in the ratio of caseinolytic to CLP activity was obtained (Table 4).

The molecular weight of the rat testis CLP was found to be about 110,000 (Text-fig. 2).

Table 4. Specific CLP and caseinolytic activities during the purification process of rat testis CLP

\begin{tabular}{l|c|c}
\hline \multicolumn{1}{c|}{ Rat testis fractions } & $\begin{array}{c}\text { Specific CLP activity } \\
\text { (units/mg protein })\end{array}$ & $\begin{array}{c}\text { Specific caseinolytic activity } \\
(\mu g \text { tyrosine/mg total proteins) }\end{array}$ \\
\hline Rat testis homogenate & $2 \cdot 77$ & $19 \cdot 10$ \\
50 to $60 \%\left(\mathrm{NH}_{4}\right)_{2} \mathrm{SO}_{4}$ fraction & $7 \cdot 61$ & Not estimated \\
60 to $70 \%\left(\mathrm{NH}_{4}\right)_{2} \mathrm{SO}_{4}$ fraction & $9 \cdot 20$ & Not estimated \\
Purified $\mathrm{CLP}($ fractions 32 and 33$)$ & $19 \cdot 79$ & $8 \cdot 20$ \\
\hline
\end{tabular}

CLP, 'collagenase-like' peptidase.

Disc gel electrophoresis revealed that purified rat testis CLP degraded heatdenatured rat skin collagen but not native collagen (Pl. 1, Figs 1 and 2).

No effect of the purified rat CLP on bovine serum albumin and porcine insulin could be demonstrated by this method.

\section{DISCUSSION}

In human semen, rat and bull epididymal spermatozoa and rat and bull testes, an enzyme has been found which is capable of degrading synthetic collagenase substrate and collagen peptides but not native collagen molecules. We have called the enzyme a 'collagenase-like' peptidase, as proposed by Sakai and colleagues (1967) for a similar enzyme in fibrotic liver. The total activity pattern of CLP in the human semen fractions (Table 1), its greatest specific activity in washed spermatozoa (Table 2) of the three species mentioned above and its presence in the epididymal spermatozoa and testis homogenate (Table 3) constitute evidence showing that it is a spermatozoal enzyme.

The GLP content of seminal plasma is probably due to release of the enzyme from the spermatozoa, since azoöspermic seminal plasma has negligible CLP activity. However, the results of the sperm washing experiment indicate that the enzyme might also come from the cytoplasmic droplets, which are known to possess hydrolytic enzymes (Dott \& Dingle, 1968).

The $\mathrm{pH}$ optima and site of cleavage of PZ-Pro-Leu-Gly-Pro-D-Arg were the same in all cases. This proves that in testes, epididymal spermatozoa, washed

\section{EXPLANATION OF PLATE 1}

FIG. 1. Disc electropherograms of an incubation mixture containing heat-denatured rat skin collagen and purified rat testis CLP after (A) $0 \mathrm{hr}$, (B) $1 \mathrm{hr}$ and (C) $2 \mathrm{hr}$ of incubation. The disappearance of the collagen bands is visible.

Fig. 2. Disc electropherograms of an incubation mixture containing native rat skin collagen and purified rat testis CLP, after (A) $0 \mathrm{hr},(\mathrm{B}) 1 \mathrm{hr}$ and (C) $2 \mathrm{hr}$ of incubation. No significant change in the collagen bands can be seen. s.g. = spacer gel; coll. = collagen peptides; GLP = purified GLP bands. 
PLATE 1
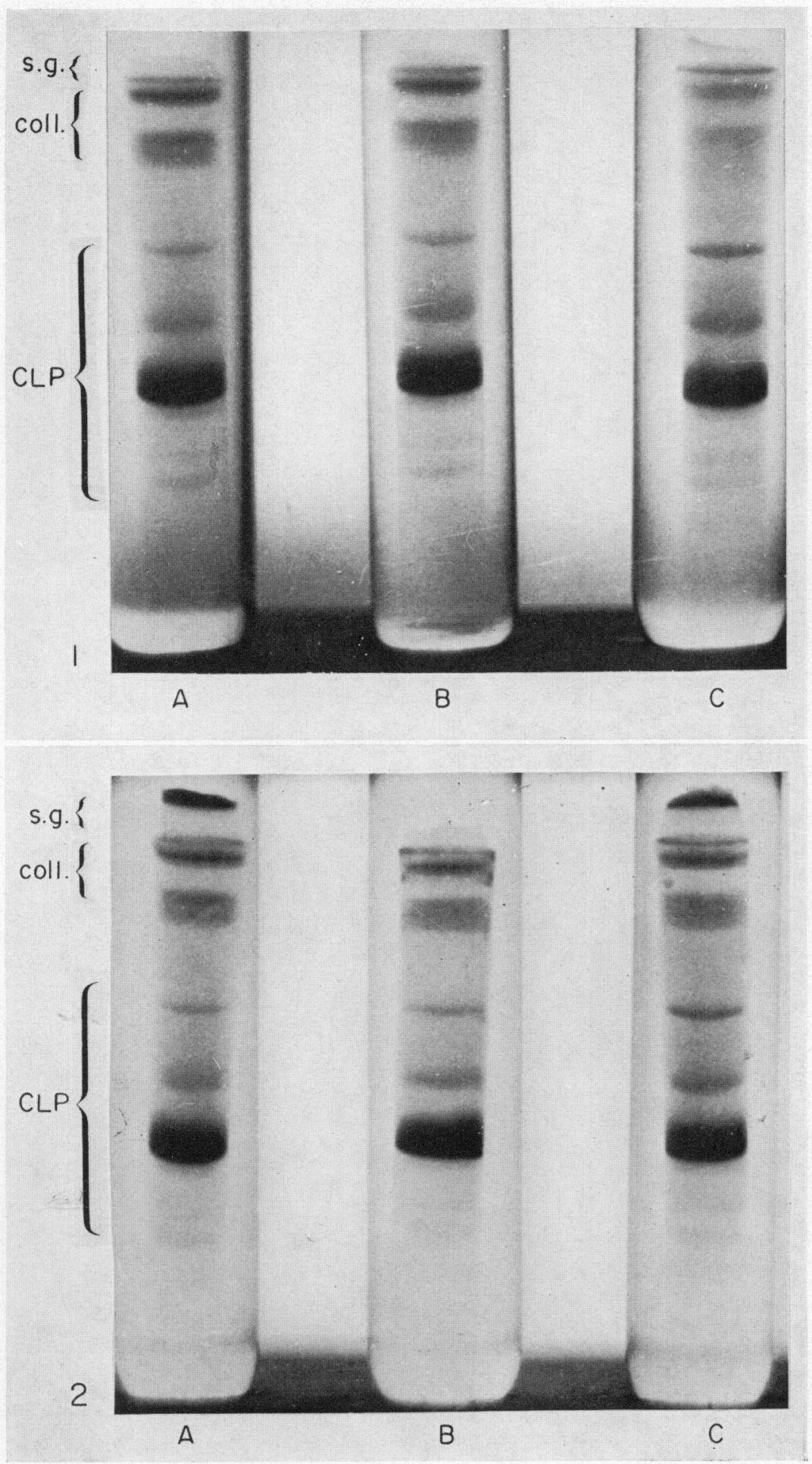

(Facing p. 354) 
spermatozoa and seminal plasma, the same enzyme is responsible for the cleavage of PZ-Pro-Leu-Gly-Pro-D-Arg.

The peptidase (or peptidases) which at physiological $\mathrm{pH}$ cleave synthetic bacterial collagenase substrates with the amino acid sequence -Pro-x-Gly-Pro-y characteristic of the apolar regions of the collagen molecule have been found in tissue cultures of He-La cells (Strauch \& Vencelj, 1967), a variety of tissues taken from rabbits (Espey \& Rondell, 1967), fibrotic liver (Sakai et al., 1967), mouse fibroblast cells, liver, bone and skin of the chick embryo (Strauch, Vencelj \& Hannig, 1968), tadpole tail fin (Harper \& Gross, 1970), calf costal cartilage (Rabadjija, Koren \& Pende, 1971) and in Graafian follicles (Espey \& Rondell, 1965). Although these enzymes cannot be considered true collagenases because they do not degrade native collagen, they do possess specificity for -Pro-x-Gly-Pro-y sequence according to some authors (Strauch, 1970; Woessner, 1970) and probably participate in the final stages of collagen degradation (Harper \& Gross, 1970). The PZ-Pro-Leu-Gly-Pro-D-Arg sequence possessing C-terminal D-arginine is resistant to non-specific proteases such as trypsin, chymotrypsin, carboxypeptidase A and B (Wünsch \& Heidrich, 1963). To a certain extent, the results of our experiments have also shown the specificity of sperm CLP because: (1) the site of cleavage of PZ-Pro-Leu-Gly-Pro-D-Arg is between -Leu and -Gly, which is characteristic of bacterial collagenase; (2) purification of CLP from the rat testis homogenate shows a decrease in the ratio of caseinolytic to CLP activity (Table 4); (3) purified CLP does not degrade bovine serum albumin or porcine insulin.

Sperm proteases have been described in several publications (Buruiana, 1956; Stambaugh \& Buckley, 1968, 1969; Ho \& Meizel, 1970; Allison \& Hartree, 1970) and have even been detected in the acrosomes. Their biological rôle is believed to be the cleavage of the zona pellucida (Stambaugh \& Buckley, 1969) or corona radiata proteins (Zaneveld \& Williams, 1970).

Since the specificity requirements and the true biological substrate of CLP have not been clearly determined so far, the rôle of such an enzyme in the spermatozoa is uncertain, but it is logical to suppose that among the substances encountered by spermatozoa (cervical mucus, uterine mucus, oviduct mucus, cumulus oophorus and zona pellucida) there is also a substrate for CLP. By the degradation of this substrate, CLP might facilitate sperm motility or penetration into the egg.

\section{ACKNOWLEDGMENTS}

This investigation was in part supported by grant No. 151 from the Yugoslav Federal Research Fund and grant No. 02-022 from the National Institutes of Health (USPHS).

\section{REFERENCES}

Allison, A. G. \& Hartree, E. F. (1970) Lysosomal enzymes in the acrosome and their possible rôle in fertilization. F. Reprod. Fert. 21, 501.

Burutana, L. M. (1956) Sur l'activité hyaluronidasique et trypsinique de sperme. Naturwissenschaften, 43, 523.

Dixon, M. \& WEBB, E. G. (1961) Enzymes, p. 43. Longmans Green, London. 
Dott, H. M. \& Dingle, J. T. (1968) Distribution of lysosomal enzymes in the spermatozoa and cytoplasmic droplets of bull and ram. Expl Cell Res. 52, 523.

EsPey, L. L. \& RondeLL, P. (1965) Measurement of proteolytic activity in the rabbit Graafian follicle. Fedn Proc. Fedn Am. Socs exp. Biol. 24, 450.

EsPEY, L. L. \& RoNDELL, P. (1967) Estimation of mammalian collagenolytic activity with a synthetic substrate. F. appl. Physiol. 23, 1757.

HARPER, E. \& Gross, J. (1970) Separation of collagenase and peptidase activities of tadpole tissues in culture. Biochim. biophys. Acta, 198, 268.

Heidrich, H. G., Prokopova, D. \& Hannig, K. (1969) The use of synthetic substrates for the determination of mammalian collagenases: is collagenolytic activity present in mitochondria? Hoppe-Seyler's Z. physiol. Chem. 350, 1430.

Ho, J. J. L. \& MeizeL, S. (1970) Electrophoretic detection of multiple forms of trypsin-like activity in spermatozoa of the domestic fowl. F. Reprod. Fert. 23, 177.

Kunitz, M. (1947) Crystalline soybean trypsin inhibitor. II. General properties. F. gen. Physiol. 30, 291.

LAPik̀re, C. M. \& Gross, J. (1965) Mechanisms of hard tissue destruction. American Association for the Advancement of Science, Publ. No. 75, p. 663. Washington.

Moghissi, K. S. \& SyNer, F. N. (1970) Studies on human cervical mucus: mucoids and their relation to sperm penetration. Fert. Steril. 21, 234.

Rabadjija, L., Koren, E. \& Pende, B. (1971) Studies on the composition of extracellular fluid from calf costal cartilage. Biochim. biophys. Acta, 230, 620.

Reisfeld, R. A., Lewis, V. J. \& Williams, D. E. (1962) Disc electrophoresis of basic proteins and peptides on polyacrylamide gels. Nature, Lond. 195, 281.

Sakai, T., Oda, T., Yoxono, Y., Igarashi, S., Suzuki, H. \& Yoshitoshi, Y. (1967) Collagenase-like peptidase activity in fibrotic liver tissue. Clinica chim. Acta, 15, 321.

Stambaugh, R., Brackett, B. G. \& Mastrolanni, L. (1969) Inhibition of in vitro fertilization of rabbit ova by trypsin inhibitors. Biol. Reprod. 1, 223.

Stambaugh, R. \& Buckley, J. (1968) Zona pellucida dissolution enzymes of the rabbit sperm head. Science, N.r. 191, 585.

Stambaugh, R. \& Buckley, J. (1969) Identification of the enzymes effecting penetration of the zona pellucida by rabbit spermatozoa. F. Reprod. Fert. 19, 423.

Stambaugh, R. \& Buckiey, J. (1970) Comparative studies of the acrosomal enzymes of rabbit, rhesus monkey and human spermatozoa. Biol. Reprod. 3, 275.

Straugh, L. (1970) Peptidyl-peptide hydrolase (collagenase) in cells of higher animals. In: Chemistry and Molecular Biology of the Intercellular Matrix, Vol. 3, p. 1675. Ed. E. A. Balazs. Academic Press, London and New York.

Strauch, L. \& VencelJ, H. (1967) Collagenases in mammalian cells. Hoppe-Seyler's Z. physiol. Chem. $348,465$.

Strauch, L., Vencelj, H. \& Hannig, K. (1968) Kollagenase in Zellen höher entwickelter Tiere. HoppeSeyler's Z. physiol. Chem. 349, 171.

Syner, F. N. \& MoGhissi, K. S. (1972) Purification and properties of a human seminal proteinase. Biochem. F. 126, 1135.

WadDELl, W. J. (1956) A simple ultraviolet spectrophotometric method for the determination of protein. F. Lab. clin. Med. 48, 311.

WoEssNer, J. F. (1970) Collagen remodelling in chick skin embryogenesis. In: Chemistry and Molecular Biology of the Intercellular Matrix, Vol. 3, p. 1663. Ed. E. A. Balazs. Academic Press, London and New York.

WüNsch, E. \& HeIDrich, H. G. (1963) Zur quantitativen Bestimmung der Kollagenase. HoppeSeyler's Z. physiol. Chem. 333, 149.

Zaneveld, L. J. D. \& Williams, W. L. (1970) A sperm enzyme that disperses the corona radiata and its inhibition by decapacitation factor. Biol. Reprod. 2, 363. 